\title{
IMPLEMENTASI SUPERIOR CUSTOMER VALUE DALAM PERSAINGAN OBYEK WISATA
}

\author{
Rusdan $^{1}$, Sulhaini ${ }^{2}$, Rahman Dayani $^{3}$ \\ ${ }^{1}$ Fakultas Ekonomi Dan Bisnis Unram, rusdan58@unram.ac.id \\ ${ }^{2}$ Fakultas Ekonomi Dan Bisnis Unram, sulhaini@unram.ac.id \\ ${ }^{3}$ Fakultas Ekonomi Dan Bisnis Unram, rahmandayani@gmail.com
}

\begin{tabular}{ll|lll}
\hline Article history & \\
\hline Dikirim tanggal & $: 14 / 01 / 2020$ & Diterima tanggal & $:$ & $8 / 09 / 2020$ \\
Revisi pertama tanggal & $: 14 / 08 / 2020$ & Tersedia online tanggal & $:$ & $29 / 9 / 2020$ \\
\hline
\end{tabular}

\begin{abstract}
ABSTRAK
Tujuan penelitian ini adalah untuk mengisi gap yakni kesesuaian antara strategi pemasaran yang selama ini digunakan dalam pengembangan obyek wisata dengan persepsi wisatawan. Penelitian ini diharapkan berkontribusi pada perkembangan model perilaku konsumen yang merupakan bagian dari materi perkuliahan Perilaku Konsumen dalam bidang kajian Manajemen Pemasaran. Populasi dalam penelitian ini adalah seluruh wisatawan yang pernah berkunjung minimal ke salah satu obyek wisata alam terpilih (Botanic Garden dan Pasar Pancingan) di Pulau Lombok dan sampel dipilih secara accidental. Pendekatan analisis yang digunakan adalah Model Matriks Konsumen yang menghubungkan antara nilai guna dan harga yang dipersepsikan oleh pengunjung. Hasil analisis menunjukkan Pasar Pancingan menerapkan persepsi harga rendah dan persepsi nilai guna yang tinggi, sedangkan Botanic Garden menerapkan persepsi harga lebih tinggi dengan persepsi nilai guna rendah. Selain itu, dilihat dari persepsi harga maupun persepsi nilai guna Pasar Pancingan memiliki posisi yang lebih baik dibandingkan dengan Botanic Garden. Meskipun demikian seluruh unsur-unsur pelayanan pada kedua obyek wisata ini masih belum memberikan kinerja yang baik, sehingga perlu mendapatkan perhatian serius untuk dikembangkan.
\end{abstract}

Kata Kunci: Superior Customer Value, Persaingan Obyek Wisata

\begin{abstract}
The purpose of this study is to fill the research gap with the hope of contributing to the development of consumer behavior models that are part of Consumer Behavior lectures in the field of Marketing Management studies.The research method used is descriptive method with a sample survey approach in some populations. This Study population was tourists who had visited one of the natural attractions (Botanic Garden and Pancingan Market). There are 50 people in each location determined accidentally. The analytical approach used is model of the Consumer Matrix. The conclusions that can be drawn are; (a) Pancingan Market is in the East with low price perception (cheap) and high PUV (perceived use value), (b) Botanic Garden is in the West path with higher price perception (expensive) and PUV perception or perceived use value low, (c) Position of the Pancingan Market seen from the perception of price and perceived value of use to have a better position compared to the Botanic Garden, (d) All service elements in the Pancingan Market and Botanic Garden still do not provide good performance and need attention serious developing.
\end{abstract}

Keywords: Superior Customer Value, Tourism Object Competition 


\section{PENDAHULUAN}

Pariwisata merupakan salah satu industri terbesar di dunia, karena melibatkan hampir seluruh penduduk bumi dan menghabiskan uang yang sangat besar. Pada kenyataannya, industri pariwisata ini memang mencakup usaha yang sangat banyak dan beragam, seperti: paket perjalanan hingga yang cakupannya paling kecil seperti liburan perorangan; dari kunjungan domestik hingga kunjungan teman dan kerabat, hingga perjalanan internasional dan antarbenua; dan dari perjalanan bisnis, rekreasi "matahari", pasir laut, olah raga, alam, kesehatan, liburan alternatif, kebudayaan dan petualangan. Dengan demikian, banyak serta beragamnya unsur-unsur dalam bisnis pariwisata dari yang berskala kecil hingga besar inilah yang mendorong industri tersebut menjadi besar dan penting.

Pulau Lombok memiliki potensi kepariwisataan yang sangat besar dan cukup lengkap, meliputi: wisata budaya, wisata atraksi dan wisata alam, yang sangat digemari oleh wisatawan. Semakin hari, semakin banyak bermunculan obyek-obyek wisata alam baru hasil kreasi manusia berupa taman-taman wisata dengan areal yang tidak luas dan banyak digemari oleh wisatawan nusantara (terutama wisatawan lokal), seperti: Taman Wisata Loang Baloq, arena kuliner Jalan Udayana, Pantai Gading, Pantai Kuranji, dan lain-lain. Setiap obyek wisata ini memiliki keunikan masing-masing, sehingga terkesan tidak terjadi persaingan antar obyek wisata tersebut.

Dua obyek wisata semacam ini yang sedang banyak digandrungi dan dikunjungi oleh masyarakat Pulau Lombok adalah Pasar Pancingan di Desa Bilebante (Kabupaten Lombok Tengah) dan Botanic Garden di Desa Narmada (Kabupaten Lombok Barat). Botanic Garden menampilkan taman bunga (alam terbuka) sebagai tempat foto-foto yang sangat indah yang dikombinasikan dengan kuliner tradisional, sementara Pasar Pancingan ditampilkan dalam kebun yang dilengkapi dengan atraksi permainan anakanak dan sport dikombinasikan dengan kuliner tradisional. Suasana Botanic Garden lebih hangat karena langsung di bawah sinar matahari (tanpa pohon pelindung), sementara Pasar Pancingan lebih sejuk karena di bawah naungan beberapa pohon besar. Kedua obyek wisata tersebut dibuka pada Hari Ahad (Botanic Garden hingga sore hari, sedangkan Pasar Pancingan hingga pukul 12.00).

Masing-masing obyek wisata ini berusaha untuk meningkatkan jumlah pengunjung dengan berbagai cara, baik melalui panambahan variasi, promosi, kegunaan, ataupun meningkatkan nilai produk. Untuk dapat bertahan dalam bisnis wisata tersebut, masing-masing obyek wisata menerapkan strategi untuk dapat memfokuskan diri kepada kebutuhan wisatawan dan kekuatan bersaing. Semakin ketatnya persaingan ini tentu saja akan berdampak pada semakin besarnya pengorbanan dan upaya-upaya obyek wisata memenangkan persaingan yakni menemukan strategi bersaing yang tepat melalui strategi yang berorientasi pada persepsi konsumen. Sayangnya, pengelola obyek wisata belum banyak menerapkan strategi berdasarkan persepsi wisatawan, melainkan hanya berdasarkan pikiran masing-masing setelah melihat fenomena pariwisata secara umum. Dengan demikian perlu dilakukan studi yang berkaitan dengan kesesuain antara strategi yang selama ini digunakan dalam pengembangan obyek wisata dengan strategi berdasarkan persepsi wisatawan. Salah satu pendekatan strategi bersaing yang berorientasi pada konsumen tersebut adalah Model Matriks Konsumen dalam rangka menciptakan nilai pelanggan superior. 


\section{Tujuan Penelitian}

Sebagaimana telah diuraikan bahwa masih ada celah penelitian (research gap) yang perlu diisi. Tujuan penelitian ini adalah mengisi research gap tersebut dengan harapan berkontribusi pada perkembangan model perilaku konsumen yang merupakan bagian dari Perilaku Konsumen terkait dengan Manajemen Pemasaran.

\section{TINJAUAN PUSTAKA}

Customer value merupakan sebuah konsep yang paling banyak digunakan oleh pelaku bisnis yang merupakan sebuah konsep sederhana dan dapat digunakan sebagai langkah awal perumusan strategi selanjutnya. Banyak keputusan strategis perusahaan atau pemilik merek menggunakan konsep ini sebagai landasan utamanya, walaupun seringkali tidak terformulasikan dengan baik. Mereka tidak menggunakan hitunganhitungan sistematis dengan analisa data yang canggih tetapi melalui judgment. Secara sederhana, customer value diartikan sebagai semua manfaat atau kualitas yang diperoleh oleh konsumen relatif terhadap pengorbanannya. Diformulasikan secara matematis, customer value adalah total manfaat atau kualitas dibagi dengan harga. Selanjutnya, rumus ini bisa berkembang karena adanya aspek harga dan kualitas.

Ada tiga komponen yang bisa mewakili kualitas yaitu: kualitas produk, kualitas pelayanan, dan emotional quality. Ini adalah kualitas yang dirasakan oleh konsumen karena pengaruh merek dan relationship (brand to customer experience). Faktor emosional ini bisa terjadi juga karena pelanggan memiliki relationship yang sangat kuat dengan perusahaan atau dengan sesama pelanggan. Mereka memiliki hubungan yang personal dan emosional. Kemenangan dari suatu merek, seringkali ditentukan oleh seberapa mampu mereka menyampaikan superior customer value kepada konsumen atau pelanggannya. Lichtenstein, Ridgway \& Netemeyer (1993:234) dan Leliana \& Suryandari (2004:111) mengemukakan bahwa harga menjadi salah satu isyarat paling dominan dalam pemasaran, karena harga ada pada semua situasi pembelian. Harga juga merupakan salah satu isyarat yang digunakan oleh konsumen dalam proses persepsi yang akan mempengaruhi penilaian konsumen tentang suatu produk.

Sebuah kebijakan harga adalah motto atau tindakan yang dirancang untuk mempengaruhi dan menentukan keputusan harga. Harus memberikan jawaban atas pertanyaan: "Bagaimana harga akan digunakan dalam bauran pemasaran" (Jennifer Rowley, 1997: 185). Kebijakan harga menentukan pertimbangan biaya pengembangan dan periode waktu di mana mereka bertujuan untuk menutup biaya ini, dan bagaimana dengan mudah dan cepatnya pesaing dapat memasuki pasar. Perusahaan-perusahaan dapat menjalankan kampanye iklan dan promosi yang sama sebagaimana digunakan di pasar dalam negeri atau mengubahnya untuk masing-masing pasar lokal, suatu proses yang disebut penyesuaian komunikasi (communication adaptation).

Konsumen yang puas adalah konsumen yang akan berbagi kepuasan dengan produsen atau penyedia jasa. Bahkan, konsumen yang puas akan berbagi rasa dan pengalaman dengan konsumen lain. Ini akan menjadi referensi bagi perusahaan. Oleh karena itu, baik konsumen maupun produsen akan sama-sama diuntungkan apabila kepuasan terjadi. Adapun faktor-faktor yang menyebabkan konsumen merasa puas 
antara lain penetapan tarif (price), kelengkapan fasilitas (facility) dan pemberian pelayanan (service). Penetapan tarif (price) terhadap suatu produk yang diberikan berhubungan dengan kualitas dan mutu suatu produk yang ditawarkan kepada konsumen. Penetapan tarif yang sesuai dengan produk yang diberikan akan membuat konsumen menjadi percaya terhadap produk tersebut sehingga menimbulkan brand image pada diri konsumen terhadap suatu produk. Brand image suatu produk diperoleh apabila konsumen merasa puas terhadap tariff yang ditetapkan pada suatu produk. Selain tarif, faktor fasilitas juga merupakan faktor yang penting dalam menentukan kepuasan konsumen. Faktor fasilitas untuk memilih suatu produk khususnya produk jasa akan membuat konsumen merasa puas terhadap produk yang dipakainya.

Kepuasan konsumen terhadap pelayanan yang diberikan merupakan faktor yang sangat penting dalam sebuah bisnis atau usaha yang bergerak dalam bidang jasa. Tjiptono (1998:146) menyatakan bahwa kepuasan merupakan tingkat perasaan setelah membandingkan kinerja yang dirasakan dengan harapan yang diinginkan, sehingga tingkat kepuasan merupakan presepsi konsumen setelah menerima pelayanan. Kualitas pelayanan merupakan tingkat keunggulan yang diharapkan dan pengendalian atas tingkat keunggulan untuk memenuhi keinginan konsumen. Kualitas pelayanan dimulai dari kebutuhan konsumen dan berakhir pada persepsi konsumen, sehingga dapat diartikan bahwa kualitas pelayanan yang baik terlihat dari persepsi konsumen terhadap produk. Persepsi konsumen terhadap kualitas pelayanan merupakan penilaian total akan keunggulan suatu produk yang berupa barang atau jasa (pelayanan).

Era globalisasi menimbulkan persaingan yang ketat di antara berbagai perusahaan. Dengan begitu banyaknya pesaing maka perusahaan perlu menerapkan market-driven strategy, sehingga perusahaan harus lebih memfokuskan diri pada kebutuhan pelanggan dan kekuatan pesaing untuk mempertahankan dan meningkatkan pangsa pasar. Hal ini tercermin dari semakin banyaknya perusahaan yang menyertakan komitmennya terhadap kepuasan konsumen. Kepuasan pelanggan menjadi sasaran strategis agar perusahaan tetap tumbuh dan berkembang serta tetap eksis dalam menghadapi perubahan persaingan yang semakin ketat.

Strategi bersaing menurut Bowman et al. (1997) adalah strategi di tingkat bisnis yang mempunyai perhatian utama pada penciptaan keunggulan kompetitif produk yang terus menerus. Cara untuk mengembangkan strategi kompetitif yang efektif adalah mengetahui dan mengerti dengan baik keunggulan kompetitif sebagai konsep kunci dalam pemasaran strategis (Robbins, 2002). Keunggulan kompetitif menurut Kotler (2010) adalah keunggulan yang dibandingkan dengan pesaing yang diperoleh dengan menyampaikan nilai yang lebih besar kepada pelanggan, harga yang lebih murah, atau dengan menyediakan lebih banyak manfaat yang sesuai walaupun dengan harga yang lebih tinggi.

Salah satu alat bantu dalam menganalisis strategi bersaing ini adalah dengan menggunakan model matriks konsumen yang merupakan pendekatan untuk mengulas strategi bersaing dalam persepsi konsumen serta memiliki dasar pengukuran yang kuat dan memiliki kekuatan dalam menilai strategi perusahaan atas dasar orientasi pasar (Tony, 2004). 


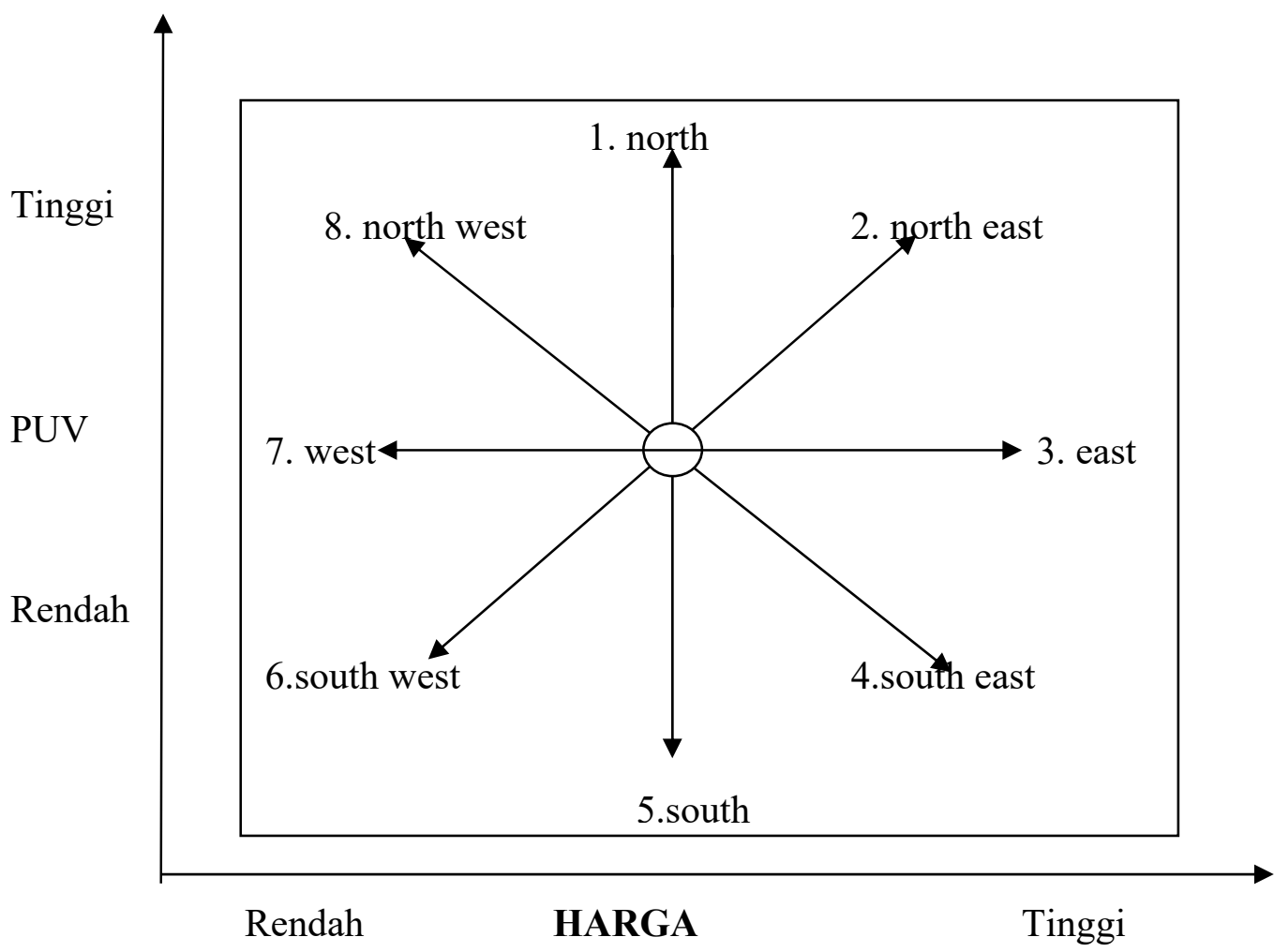

Gambar 1. Model Matriks Konsumen (Tony, 2004)

Model matriks konsumen berkaitan erat dengan strategi perusahaan yang dimodifikasi dari clock stratregic model dengan mengubah price dan value added menjadi perceived value dan perceived use value (PUV). Pemikiran yang melatarbelakangi modifikasi ini adalah konsumen lebih berpengalaman dan lebih menuntut produk yang lebih memuaskan mereka. Konsumen mulai menyadari tidak hanya memperhatikan harga, melainkan juga biaya pemeliharaan, operasional dan lainlain. Ada 8 kemungkinan arah dalam model matrik konsumen, yaitu : north, north east, east, south east, south, south west, west, dan north west, sebagaimana dapat dilihat pada gambar berikut.

Matriks konsumen ini dipakai sebagai alat ukur untuk mengetahui posisi perusahaan dalam persaingan. Untuk menciptakan sustainable competitive advantage dapat dilakukan menciptakan gap antara produk milik sendiri dengan produk pesaing. Gap akan tercipta jika perusahaan menambah PUV dengan langkah menentukan pelanggan sasaran, mengetahui nilai pelanggan sasaran, dan mewujudkan nilai pelanggan ke dalam produknya. Setelah itu perusahaan akan terus-menerus menciptakan gap dengan menjadi inovator atau first follower, terus belajar, dan terus menerus melakukan inovasi yang memiliki nilai. Perusahaan perlu juga mempertahankan diferensiasi dengan menciptakan perubahan biaya, mempromosikan merek dan reputasi, mencegah pemalsuan, meraih hearthshare, mengontrol jalur distribusi, menciptakan dimensi PUV yang baru. 
Rute 1 (satu) terjadi saat perusahaan meningkatkan daya saing melalui upaya menaikkan PUV yang penting bagi konsumen dan sulit ditiru oleh pesaing dengan tanpa meningkatkan harga. Upaya ini tentu sulit dilakukan oleh perusahaan, karena umumnya peningkatan PUV memiliki konsekwensi langsung terhadap biaya dan harga. Yang paling sulit (lebih sulit daripada rute satu) tentu saja rute 8, yakni perusahaan meningkatkan PUV dengan jalan menurunkan harga. Dengan strategi ini perusahaan akan memiliki jaminan memperoleh market share yang lebih besar karena mampu menunjukkan kinerja yang lebih baik dengan harga yang lebih rendah daripada sebelumnya.

Rute dua dilakukan dengan jalan meningkatkan PUV yang diimbangi dengan peningakatan harga. Keberhasilan strategi ini sangat tergantung pada kemauan konsumen membayar lebih banyak untuk PUV yang lebih tinggi dan tingkat kesulitan peniruan PUV-nya yang tinggi.

Rute tiga dilakukan jika perusahaan menaikkan harga tanpa penambahan PUV yang dapat meningkatkan profitabilitas. Hal ini biasanya juga dilakukan oleh perusahaan yang mengalami kenaikan harga bahan mentah, yang menyebabkan meningkatnya biaya produksi.

Rute empat layak dilakukan bila terdapat keterbatasan penawaran yang memiliki kecenderungan akan mengecewakan konsumen dalam jangka pendek. Implementasi strategi adalah dengan menurunkan PUV dan menaikkan harga. Biasanya hal ini dilakukan oleh perusahaan yang mengalami kenaikan biaya produksi dan manajemen ingin menambah profitabilitas.

Untuk rute lima dilakukan dengan jalan menurunkan PUV pada harga yang stabil. Penurunan kualitas PUV akan dapat memicu kekecewaan konsumen aktual perusahaan. Penurunan kualitas PUV ini juga dilakukan pada rute 6 , namun masih lebih baik yakni diiringi dengan penurunan harga. Strategi akan mendorong perusahaan bergerak ke arah segmen pasar baru yang merupakan penurunan pasar.

Rute tujuh terjadi jika perusahaan menurunkan harga tanpa mengubah kualitas PUV yang lebih disenangi oleh konsumen yang sudah dikuasai. Mereka akan mengeluarkan biaya yang lebih sedikit untuk memperoleh pelayanan yang sama. Dan konsumen akan lebih menyukai rute delapan yang diimplementasikan dalam bentuk peningkatan PUV dengan diiringi oleh penurunan harga. Hal ini hanya dilakukan oleh perusahaan yang mampu berproduksi secara sangat efesien dengan tetap mempertahankan profitabilitas agar perusahaan tetap dapat meningkatkan kinerjanya. Strategi dalam rute ini dikenal dengan strategi pemenangan karena konsumen akan menerima PUV yang lebih tinggi daripada pesaing dengan harga yang lebih murah.

Isu keunggulan bersaing obyek wisata secara berkelanjutan yang meliputi aspek ekonomi, lingkungan, dan masyarakat perlu dipertimbangkan dalam menghadapi pergerakan terus ke arah persaingan yang lebih baik. Pilihan dasar yang dapat dipakai oleh obyek wisata adalah bergerak terus meningkatkan PUV dan berada selangkah lebih depan daripada pesaingnya melalui inovasi produk pariwisata atau melakukan pemotongan harga. Meskipun demikian pemotongan harga memiliki kecenderungan akan berdampak pada penurunan kinerja secara keseluruhan industri pariwisata (jika seluruh pesaing melakukan upaya yang sama). Dari sudut pandang wisatawan adanya harga jual yang lebih rendah tentunya akan sangat menguntungkan. Wisatawan tidak terlalu perduli dengan adanya perang tarif yang dilakukan pelaku usaha. Apalagi 
dengan adanya kondisi perekonomian Indonesia yang masih belum pulih, sehingga terjadi perubahan pada pola konsumtif yang melahirkan smart consumer (Mardiharto, 2008). Konsumen menjadi semakin peduli terhadap perubahan harga suatu produk dan tidak lagi menjadi konsumen yang fanatik terhadap suatu produk tertentu.

Secara teori dengan berjalannya prinsip-prinsip persaingan usaha yang sehat pada suatu pasar akan membawa dampak yang positif kepada baik bagi produsen/ pelaku usaha maupun konsumen, pada pasar yang bersangkutan. Secara langsung adanya persaingan yang sehat antar pelaku usaha akan memaksa pelaku usaha untuk dapat menjual produk barang atau jasanya dengan harga yang serendah mungkin dengan tetap mempertahankan mutu atau bahkan meningkatkan mutu dari produk barang dan jasanya

(Hansen, 2002). Hal ini tentunya akan sangat menguntungkan wisatawan disamping itu konsumen juga akan memperoleh keuntungan berupa kemampuan untuk memilih barang atau jasa yang dipasarkan, karena banyaknya pelaku usaha yang menawarkan produknya. Secara tidak langsung dalam kondisi pasar persaingan murni, agar tetap dapat obyek wsiata bertahan harus mampu meningkatkan efisiensi dan produktivitasnya agar mampu bersaing dengan pelaku usaha lainnya. Pelaku usaha dituntut untuk dapat menciptakan inovasi-inovasi baru agar produk barang atau jasanya mempunyai unsur pembeda atau nilai lebih dengan produk sejenisnya, sehingga dipilih oleh konsumen

Berwisata saat ini sudah menjadi kebutuhan sebagian masyarakat dan bukan lagi produk mewah yang didominasi oleh sekelompok orang berduit yang mampu melakukan kegiatan berwisata mahal yang sekaligus juga berfungsi sebagai simbol status. Hampir semua obyek wisata menawarkan tarif yang relatif lebih murah untuk akses obyek wisata tersebut, bahkan ada yang membebaskan pembayaran memasuki obyek wisatanya. Pada dasarnya iklim persaingan yang dihadapi oleh pengelola obyek wisata masih sangat sehat, tidak ada saling jegal dan saling menjelekkan. Dengan demikian terbuka peluang kerjasama antar obyek wisata untuk saling memasarkan obyek wisata lainnya.

\section{METODE PENELITIAN}

Metode yang digunakan dalam penelitian ini adalah metode deskriptif dengan menggunakan pendekatan sampel survei pada sebagian populasi. Digunakannya metode penelitian ini dimaksudkan untuk memberikan gambaran yang komprehensif tentang posisi persaingan kedua obyek wisata alam buatan di Pulau Lombok. Data utama yang dibutuhkan dalam penelitian ini berupa data primer yang bersumber dari wisatawan yang berkunjung ke Botanic Garden dan Pasar Pancingan. Teknik pengumpulan data, yakni: observasi dan angket.

Populasi dalam penelitian ini adalah seluruh wisatawan yang pernah berkunjung ke salah satu obyek wisata alam (Botanic Garden dan Pasar Pancingan) di Pulau Lombok yang jumlahnya tidak diketahui atau tidak dapat diidentifikasi dengan jelas. Berdasarkan pertimbangan sulitnya memperoleh informasi tentang daftar seluruh wisatwan tersebut, maka teknik sampling yang digunakan adalah accidental sampling yakni wisatawan yang kebetulan dijumpai pada saat sedang berada di salah satu obyek wisata tersebut. Berdasarkan kenyataan banyaknya jumlah wisatawan yang berkunjung, 
maka penelitian ini hanya menentukan jumlah responden wisatawan masing-masing sebanyak 50 orang di setiap obyek wisata.

Untuk pencapaian tujuan penelitian, data akan dianalisis secara kualitatif dan kuantitatif dengan bantuan komputer yakni menyusun menyusun matriks konsumen, dengan langkah: (a). Mengidentifikasi segmen pasar, (b). Mengidentifikasi dimensi perceived use value (PUV), (c) Penentuan tingkat kepentingan dimensi-dimensi PUV, (d). Penentuan perceived price (persepsi harga), e) Menaksir Kinerja tiap obyek wisata pada sumbu PUV, (f) Menetapkan posisi dalam matriks .

\section{HASIL DAN PEMBAHASAN}

\section{Persepsi responden terhadap obyek wisata}

Banyak hal yang dipersepsikan oleh responden wisatawan yang berkunjung ke Botanic Garden Narmada dan Pasar Pancingan Bilebante, seperti menyangkut: harga, tingkat kepentingan, dan kepuasan terhadap sebagian besar aspek pelayanan yang ada di dalam kawasan wisata tersebut. Aspek pelayanan yang dinilai meliputi: lingkungan, fasilitas pendukung, waktu operasional, lokasi, komunikasi, petugas, dan tarif masingmasing item. Khusus di Pasar Pancingan dan Botanic Garden harga-harga makanan, minuman, dan wahana wisata yang ditawarkan kepada wisatawan dapat digolongkan murah dalam persepsi responden yakni dengan harga yang hampir sama di luar kawasan wisata. Umumnya di tempat-tempat wisata harga ditetapkan agak mahal oleh pengelola atau pedagang mengingat adanya kondisi spesial dan keterbatasan produk (keterpaksaan konsumen). Bahkan untuk di Pasar Pancingan kesannya harga-harga lebih murah daripada di luar obyek wisata. Harga relatif tinggi diterapkan oleh Botanic Garden untuk paket penyewaan pakain tradisional Jepang lengkap dengan juru photonya yakni sebesar Rp 50.000,- untuk 15 moment photo (gambar), mengingat paket semacam ini masih sangat langka di Pulau Lombok. Persepsi responden terhadap harga-harga yang ditetapkan dalam obyek wisata tersebut dapat dilihat pada tabel 1 .

Tabel 1. Persepsi Responden Terhadap Harga di Obyek Wisata

\begin{tabular}{|c|l|c|c|c|c|}
\hline \multirow{2}{*}{ No. } & \multirow{2}{*}{ Persepsi Terhadap Harga } & \multicolumn{2}{|c|}{ Pasar Pancingan } & \multicolumn{2}{c|}{ Botanic Garden } \\
\cline { 3 - 6 } & & Jumlah & \% & Jumlah & \% \\
\hline 1 & Sangat Mahal & 0 & 0,00 & 1 & 1,47 \\
\hline 2 & Mahal & 8 & 14,29 & 5 & 7,35 \\
\hline 3 & Sedang & 12 & 21,43 & 38 & 55,88 \\
\hline 4 & Murah & 6 & 10,71 & 18 & 26,47 \\
\hline 5 & Sangat Murah & 30 & 53,57 & 6 & 8,82 \\
\hline \multicolumn{2}{|c|}{ Jumlah } & 56 & 100 & 68 & 100 \\
\hline
\end{tabular}

Sumber : Data Primer

Sebagian besar responden Pasar Pancingan mempersepsikan sangat murah untuk produk-produk yang ditawarkannya. Dengan hanya berbekal Rp25.000,- pengunjung sudah dapat menikmati kuliner tradisional lengkap dari air minum, jajanan, dan makanan berat dengan kuantitas dan kualitas yang cukup baik. Sementara itu, sebagian besar pengunjung Botanic Garden mempersepsikan harga-harga yang mereka tawarkan cukup murah (sedang) karena berada pada kisaran harga pasar umumnya. Selain itu, 
masih ada responden yang menganggap harga di Botanic garden sangat mahal. Hal ini harus menjadi perhatian tersendiri bagi pengelola Botanic Garden agar dapat meningkatkan persepsi pengunjung menyangkut harga tersebut.

Secara umum, dimensi pelayanan yang dinilai oleh pengunjung menuntut adanya perhatian yang serius dari pengelola obyek wisata. Hampir seluruh responden memberikan porsi nilai yang tinggi untuk seluruh dimensi pelayanan yang diberikan oleh obyek wisata. Porsi nilai ini menunjukkan tingkat pentingnya dimensi pelayanan ini dalam persepsi wisatawan, semakin tinggi porsi nilai tersebut semakin tinggi pula tingkat pentingnya dimensi tersebut dalam benak responden. Perhatikan Tabel 2 berikut ini.

Tabel 2. Porsi Nilai Dimensi Global

\begin{tabular}{|c|l|c|c|c|c|c|c|c|c|c|l|}
\hline \multirow{2}{*}{ No. } & \multirow{2}{*}{ Dimensi Global } & \multicolumn{7}{|c|}{ Porsi Nilai } & \multirow{2}{*}{ JML } & \multirow{2}{*}{$\begin{array}{l}\text { Total } \\
\text { Skor }\end{array}$} & \multirow{2}{*}{ Mutu } \\
\cline { 3 - 10 } & & $\mathbf{1}$ & $\mathbf{2}$ & $\mathbf{3}$ & $\mathbf{4}$ & $\mathbf{5}$ & $\mathbf{6}$ & $\mathbf{7}$ & & 6,05 & ST \\
\hline A & Kondisi Lingkungan & 0 & 0 & 3 & 8 & 15 & 29 & 45 & 100 & 6,13 & ST \\
\hline B & Fasilitas Pendukung & 0 & 0 & 1 & 7 & 17 & 28 & 47 & 100 & 6,62 & ST \\
\hline C & Waktu Operasi & 0 & 0 & 3 & 14 & 26 & 32 & 25 & 100 & 5,62 \\
\hline D & Lokasi / Tempat & 0 & 0 & 3 & 10 & 23 & 27 & 37 & 100 & 5,85 & ST \\
\hline E & Komunikasi & 0 & 0 & 4 & 3 & 7 & 23 & 63 & 100 & 6,38 & SST \\
\hline F & Petugas & 0 & 0 & 6 & 10 & 26 & 26 & 32 & 100 & 5,68 & ST \\
\hline G & Tarif & 0 & 3 & 11 & 14 & 19 & 27 & 26 & 100 & 5,34 & ST \\
\hline
\end{tabular}

Sumber: Data Primer $\quad$ ST $=$ Sangat Tinggi $\quad$ SST $=$ Sangat Sangat

Tinggi

Terlihat bahwa sebagian besar responden memberikan porsi nilai yang tinggi (poin 5 hingga 7) pada seluruh dimensi pelayanan global yang ditanyakan, hanya sedikit responden yang menganggap dimensi global tersebut kurang penting dengan porsi nilai yang rendah. Terdapat responden yang tidak terlalu memperhatikan tarif untuk menikmati pelayanan dalam obyek wisata, karena bagi mereka uang bukan persoalan lagi selama mampu memberikan kepuasan yang tinggi. Dimensi tarif memperoleh porsi penilaian yang rendah, karena wisatawan menyadari bahwa untuk memperoleh pelayanan wisata yang baik tentu saja harus membayar dan mereka yakin tarif yang mereka bayarkan akan sesuai atau seimbang dengan pelayanan yang mereka terima. Meskipun demikian, bukan berarti dimensi tarif ini dapat diabaikan oleh pengelola obyek wisata, karena bagaimanapun juga tetap akan memberikan "warna" dalam pengambilan keputusan berwisata.

Jika diperhatikan lebih seksama, komunikasi dipandang memiliki porsi nilai yang paling tinggi dalam persepsi responden dengan mutu sangat sangat tinggi, terlihat dari lebih dari setengah responden yang memberikan nilai tertinggi (poin 7) terhadap dimensi global ini. Wisatawan memandang komunikasi yang baik memberikan informasi yang pasti, baik, dan benar sangat penting dalam mempengaruhi wisatawan memanfaatkan pelayanan obyek wisata. Berikutnya, fasilitas pendukung juga menjadi dimensi global yang memiliki penilaian tinggi. Hal ini menunjukkan bahwa wisatawan benar-benar memperhatikan keberadaan fasilitas pendukung yang ada. Tanpa kesediaan fasilitas pendukung yang baik, obyek wisata akan banyak ditinggalkan wisatawan. Mereka akan bercerita kepada rekan, keluarga, dan orang-orang di sekitarnya tentang kualitas fasilitas pendukung tersebut. Kualitas fasilitas pendukung harus ditunjukkan 
secara phisik, karena merupakan salah satu dimensi yang dinilai atau diamati oleh wisatawan. Oleh karena itu, dimensi fasilitas pendukung ini memiliki porsi nilai yang tinggi juga dalam persepsi wisatawan.

Dimensi yang tidak kalah pentingnya dalam persepsi wisatawan yang sangat perlu diperhatikan oleh pengelola obyek wisata adalah kondisi lingkungan, karena bagaimanapun juga obyek wisata yang menggunakan prinsip ekowisata faktor lingkungan merupakan pertimbangan utama. Perhatian terhadap lingkungan yang menyangkut kebersihan, keindahan, kenyamanan, keamanan, dan lain-lain sebaiknya harus didahulukan terlebih lagi menyangkut isu global pengurangan sampah plastik yang berarti mengurangi penggunaan produk berbahan plastik. Upaya pengelola Pasar Pancingan yang mendorong penggunaan alat-alat makan dan minum berbahan tanah liat (tembikar) atau bambu/kayu patut diberikan apresiasi yang tinggi karena sudah mulai menerapkan pariwisata berkelanjutan yang ramah lingkungan.

Jika ditelisik lebih jauh lagi pada indikator masing-masing dimensi akan dapat dilihat tingkat kepentingan nilai guna masing-masing usur pelayanan tersebut, sebagaimana dapat dilihat pada Tabel 3. Terlihat bahwa hanya sedikit unsur pelayanan obyek wisata yang dipandang memiliki kepentingan tinggi dari 29 unsur pelayanan, yakni: harga kuliner, harga cinderamata, tarif wahana, daya tanggap petugas, kerapihan petugas, papan petunjuk, pusat informasi, hari dan jam operasi, variasi jenis tanaman, kelengkapan wahana, dan luas kawasan obyek. Sedangkan unsur-unsur pelayanan lainnya dipandang memiliki tingkat kepentingan yang sangat tinggi dalam persepsi wisatawan. Jika diperhatikan secara lebih teliti nampak bahwa unsur jarak dari rumah dan cinderamata berada pada level kepentingan paling bawah dan mendekati cukup penting, bahkan terdapat wisatawan yang menyatakan sangat tidak penting untuk unsur pelayanan jarak dari tempat tinggal dan kegiatan promosi. Artinya bahwa wisatawan tidak terlalu meperhatikan unsur pelayanan tersebut dan menganggap bahwa unsur tersebut biasa-biasa saja.

Tabel 3. Tingkat Kepentingan Nilai Guna Unsur-unsur Pelayanan

\begin{tabular}{|c|c|c|c|c|c|c|c|c|c|}
\hline \multirow{3}{*}{ No. } & \multirow{3}{*}{ Dimensi } & \multicolumn{5}{|c|}{ Tingkat Kepentingan } & \multirow{3}{*}{ Jml. } & \multirow{2}{*}{\multicolumn{2}{|c|}{ Kepentingan }} \\
\hline & & \multirow{2}{*}{$\frac{\text { STP }}{1}$} & \multirow{2}{*}{\begin{tabular}{|c|} 
TP \\
2 \\
\end{tabular}} & \multirow{2}{*}{$\begin{array}{c}\text { CP } \\
3\end{array}$} & \multirow{2}{*}{$\begin{array}{l}P \\
4\end{array}$} & \multirow{2}{*}{$\begin{array}{c}\text { SP } \\
5\end{array}$} & & & \\
\hline & & & & & & & & Skor & Mutu \\
\hline $\mathbf{A}$ & Dimensi Lingkungan & & & & & & & & \\
\hline 1. & Kebersihan & & & 7 & 29 & 64 & 100 & 4,57 & Sgt Tinggi \\
\hline 2. & Keindahan & & & 5 & 28 & 67 & 100 & 4,62 & Sgt Tinggi \\
\hline 3. & Keamanan & & & 4 & 20 & 76 & 100 & 4,72 & Sgt Tinggi \\
\hline 4. & Kenyamanan & & & 5 & 28 & 67 & 100 & 4,62 & Sgt Tinggi \\
\hline 5. & Luas kawasan obyek & & 1 & 18 & 55 & 25 & 99 & 4,05 & Tinggi \\
\hline 6. & Kelengkapan atraksi / wahana & & 1 & 17 & 46 & 35 & 99 & 4,16 & Sgt Tinggi \\
\hline 7. & Kerapihan Obyek & & & 11 & 43 & 46 & 100 & 4,35 & Sgt Tinggi \\
\hline 8. & Variasi Jenis Tanaman & & 2 & 17 & 49 & 32 & 100 & 4,11 & Tinggi \\
\hline B & Fasilitas Pendukung & & & & & & & & \\
\hline 9. & Toilet & & & 5 & 24 & 71 & 100 & 4,66 & Sgt Tinggi \\
\hline 10. & Tempat duduk & & & 13 & 45 & 42 & 100 & 4,29 & Sgt Tinggi \\
\hline 11. & Tempat berteduh & & & 11 & 41 & 48 & 100 & 4,37 & Sgt Tinggi \\
\hline 12. & Tempat Beribadah & & & 6 & 26 & 68 & 100 & 4,62 & Sgt Tinggi \\
\hline 13. & Tempat parkir & & 1 & 8 & 40 & 50 & 99 & 4,40 & Sgt Tinggi \\
\hline 14. & Panggung Hiburan & & & 6 & 22 & 71 & 99 & 4,66 & Sgt Tinggi \\
\hline 15. & Spot Photo atau selfi & & 1 & 14 & 34 & 51 & 100 & 4,35 & Sgt Tinggi \\
\hline
\end{tabular}




\begin{tabular}{|c|c|c|c|c|c|c|c|c|c|}
\hline \multirow{3}{*}{ No. } & \multirow{3}{*}{ Dimensi } & \multicolumn{5}{|c|}{ Tingkat Kepentingan } & \multirow{3}{*}{ Jml. } & \multirow{2}{*}{\multicolumn{2}{|c|}{ Kepentingan }} \\
\hline & & \multirow{2}{*}{\begin{tabular}{|c|} 
STP \\
1 \\
\end{tabular}} & \multirow{2}{*}{$\begin{array}{c}\text { TP } \\
2\end{array}$} & \multirow{2}{*}{$\begin{array}{c}\mathbf{C P} \\
3\end{array}$} & \multirow{2}{*}{$\begin{array}{l}P \\
4\end{array}$} & \multirow{2}{*}{$\begin{array}{c}\text { SP } \\
5\end{array}$} & & & \\
\hline & & & & & & & & Skor & Mutu \\
\hline C & Waktu Operasi & & & & & & & & \\
\hline 16. & Jam beroperasi & & 4 & 26 & 45 & 24 & 99 & 3,90 & Tinggi \\
\hline 17. & Hari beroperasi & & 3 & 25 & 48 & 23 & 99 & 3,92 & Tinggi \\
\hline D & Lokasi / Tempat & & & & & & & & \\
\hline 18. & Akses transportasi & & 2 & 13 & 46 & 37 & 98 & 4,20 & Tinggi \\
\hline 19. & Jarak dari rumah & 3 & 12 & 31 & 36 & 18 & 100 & 3,54 & Tinggi \\
\hline $\mathbf{E}$ & Komunikasi & & & & & & & & \\
\hline 20. & Kegiatan Promosi & 1 & 2 & 12 & 43 & 42 & 100 & 4,23 & Sgt Tinggi \\
\hline 21. & Papan Petunjuk & & & 25 & 47 & 28 & 100 & 4,03 & Tinggi \\
\hline 22. & Pusat Informasi & & & 34 & 35 & 33 & 100 & 3,99 & Tinggi \\
\hline $\mathbf{F}$ & Petugas & & & & & & & & \\
\hline 23. & Keramahan petugas & & & 9 & 36 & 55 & 100 & 4,46 & Sgt Tinggi \\
\hline 24. & Kesopanan Petugas & & & 9 & 36 & 55 & 100 & 4,46 & Sgt Tinggi \\
\hline 25. & Kedisiplinan petugas & & 1 & 12 & 43 & 44 & 100 & 4,30 & Sgt Tinggi \\
\hline 26. & Kerapihan petugas & & 1 & 17 & 43 & 39 & 100 & 4,20 & Sgt Tinggi \\
\hline 27. & Daya tanggap petugas & & & 18 & 44 & 38 & 100 & 4,20 & Tinggi \\
\hline 28. & Kejujuran Petugas & & & 7 & 37 & 55 & 99 & 4,48 & Sgt Tinggi \\
\hline G & Tarif / Harga & & & & & & & & \\
\hline 29. & Kuliner & & 2 & 20 & 39 & 39 & 100 & 4,15 & Tinggi \\
\hline 30. & Souvenir / cinderamata & & 11 & 27 & 40 & 20 & 98 & 3,70 & Tinggi \\
\hline 31. & Wahana & & 3 & 15 & 47 & 34 & 99 & 4,13 & Tinggi \\
\hline
\end{tabular}

Sumber : Data Primer

Dengan demikian secara umum dapat dikatakan bahwa seluruh unsur pelayanan yang ada harus menjadi perhatian yang serius dari pengelolanya, karena dipandang penting bahkan sangat penting oleh wisatawan.

Implementasi unsur-unsur pelayanan yang dilakukan oleh pengelola obyek wisata yang ada secara umum dipandang belum banyak memberikan kinerja yang tinggi dalam persepsi wisatawan. Secara umum dapat dikatakan bahwa pelayanan obyek wisata buatan (Pasar Pancingan dan Botanic Garden) belum menunjukkan kinerja yang signifikan, mengingat Indeks Kepuasan Pengunjung obyek wisata tersebut masih tergolong rendah yakni hanya mencapai 3,58 masuk dalam kategori Puas di level bawah. Capaian tingkat kepuasan yang masih tergolong rendah ini harus menjadi perhatian pengelola obyek wisata dengan memperhatikan kinerja setiap unsur pelayanan yang ada. Hanya satu unsur pelayanan yakni papan petunjuk aja yang mampu memberikan kepuasan pada level tertinggi (sangat memuaskan) kepada wisatawan, sementara unsur lainnya baru pada level memuaskan bahkan ada yang baru mencapai sedang atau cukup memuaskan (souvenir, toilet, tempat ibadah, dan panggung hiburan).

Keberadaan tempat beribadah juga nampaknya belum memberikan kinerja yang baik atau memuaskan, meskipun pengelola telah membangun tempat ibadah. Artinya bahwa pengunjung mengharapkan tampilan tempat ibadah yang lebih luas, representatif, sejuk, dan dengan peralatan ibadah yang lebih bagus lagi. Pada saat waktu shalat tiba dan banyak yang ingin melaksanakan ibadah shalat pada saat bersamaan, besar kemungkinan terjadi antrian mulai dari toilet, tempat berwudhu, hingga ke tempat shalat. Selain itu, tempat atau panggung hiburan juga belum 
memberikan kepuasan yang tinggi, karena belum memberikan kinerja yang baik. Di Pasar Pancingan Bilebante terdapat panggung hiburan yang diisi dengan penampilan musik sederhana pemuda desa setempat dengan lagu-lagu yang digemari oleh pengunjung. Wisatawan juga diberikan kesempatan untuk menujukkan kebolehannya memanfaatkan panggung hiburan tersebut baik secara individu maupun kelompok. Panggung hiburan tersebut juga dapat dimanfaatkan oleh pengelola untuk memberikan informasi (sekaligus promosi) kepada pengunjung tentang Pasar Pancingan, Paket Wisata Desa Wisata Hijau Jari Solah, dan Desa Bilebante umumnya, sehingga keberadaan panggung hiburan tersebut memberikan manfaat yang besar baik bagi pengunjung maupun pengelola.

Toilet ternyata juga dipandang memiliki kinerja yang belum bagus, padahal Botanic Garden sudah membangun beberapa buah toilet (secara berjajar) dengan kondisi yang sangat bagus dan bersih. Posisi toilet berada di jalan yang dilewati pengunjung pada saat baru memasuki area obyek wisata. Sebenarnya secara umum tidak ada yang salah dengan posisi itu, namun bagia sebagian orang keberadaan toilet di posisi depan area taman wisata nampaknya kurang pas.

Gambaran lengkap tentang tingkat kepuasan wisatawan terhadap pelayanan wisata masing-masing obyek dapat dilihat pada Table 4.12 dan Table 4.13 di laporan penelitian. Kinerja pelayanan secara umum yang dilakukan oleh Botanic Garden belum dapat memberikan kepuasan kepada pengunjungnya pada level yang signifikan, karena baru mencapai kepuasan 3,54 (pada skala kepuasan tertinggi 5), yang berarti masih pada level puas yang mendekati cukup puas. Dengan demikian, dibutuhkan upaya yang sangat agresif dari pengelola Botanic Garden untuk bisa mendongkrak kepuasan pengunjungnya ke level yang lebih tinggi (sangat puas) atau minimal mendekati sangat puas. Hanya satu unsur pelayanan wisata yang memperoleh nilai kepuasan di atas 4 yakni papan petunjuk, sementara unsur pelayanan lainnya berada di bawah nilai 4 bahkan beberapa diantaranya mendekati nilai 3 .

Aspek pelayanan yang dinilai agak tinggi memberikan kepuasan pengunjungnya adalah spot photo atau selfie, karena Botanic Garden menyediakan tempat photo yang banyak, indah, dan kreatif. Hampir seluruh titik atau tempat yang ada di dalam kawasan Botanic Grden bisa dijadikan tempat photo yang bagus. Pengelola obyek wisata ini menata kawasannya dengan penuh rencana dan terpelihara, sehingga selalu terlihat ada petugas pemelihara yang memperbaiki atau memelihara tanaman bunga dan seluruh aset wisata tersebut. Dibuatnya tempat photo dengan nuansa tradisional Jepang lengkap dengan penyewaan pakaian tradisional Jepang memberikan nilai lebih kinerja pelayanan obyek ini terhadap kepuasan konsumen.

Unsur-unsur aspek lingkungan obyek wisata yang sudah ditata rapi, indah, bersih, nyaman, dan bervariasi yang dilakukan pengelola Botanic Garden ternyata belum memberikan kepuasan yang tinggi kepada pengunjungnya. Nampaknya pengunjung memiliki harapan yang lebih tinggi terhadap unsur-unsur lingkungan ini daripada yang mampu diberikan atau dilakukan oleh pengelola Botanic Garden, sehingga belum dapat memberikan kepuasan yang tinggi kepada pengunjungnya. Masih cukup banyak pengunjung yang menyatakan tidak puas bahkan sangat tidak puas terhadap unsurunsur lingkungan ini. Khusus untuk kelengkapan wahana atau atraksi di Botanic Garden lebih banyak pengunjung yang menyatakan kekurangpuasannya daripada yang sudah puas. Pada saat berada di dalam kawasan pengunjung hanya disuguhi oleh 
pemandangan indah sebagai dampak pengaturan kumpulan pohon bunga dengan paduan warna yang serasi dan indah yang cocok untuk spot photo, namun setelah puas berphoto wisatawan tidak memperoleh sesuatu yang lain lagi, kecuali untuk anak-anak atau siapa saja yang mau memanfaatkan kolam renang.

Pada sisi tarif, sangat banyak responden yang mengungkapkan ketidakpuasannya untuk harga cinderamata yang bisa mereka bawa pulang. Cinderamata yang disediakan oleh pengelola Botanic Garden berupa pohon-pohon (bunga dan tanaman buah-buahan) dengan harga yang variatif (sesuai jenisnya). Bagi pengunjung Botanic Garden mungkin saja harga tanaman tersebut dipandang masih tergolong mahal, sehingga memberikan kepuasan yang sangat rendah. Lebih luas lagi, seluruh unsur pelayanan dari sisi tarif atau harga tersebut menunjukkan kinerja pelayanan yang memberikan tingkat kepuasan paling rendah dibandingkan dengan unsur-unsur pelayanan lainnya. Hanya terdapat satu warung (tempat belanja) di dalam kawasan tersebut yang menjual berbagai kebutuhan makanan dan minuman ringan hingga berat (nasi) dengan menu yang variatif (ikan goreng, ayam goreng, pelecing, mie instan, dan lain-lain). Sayangnya pilihan menu yang disediakan dipandang biasa-biasa saja dan tidak memberikan sensasi sebagaimana saat menikmati menu yang istimewa.

Selain itu, fasilitas pendukung seperti: tempat parkir kendaraan yang cukup luas dan aman, tempat duduk yang banyak, tempat berteduh yang banyak dan tersebar, toilet yang bersih, dan tempat hiburan seadanya dipandang belum sesuai dengan harapan pengunjung, sehingga belum memberikan kepuasan yang tinggi kepada pengunjungnya. Seluruh fasilitas pendukung tersebut hanya mampu menghasilkan indeks kepuasan pengunjung di bawah nilai 3,5 yang mendekati batas bawah pada level puas. Sedikit lebih bagus dari kinerja fasilitas pelayanan tersebut adalah penampilan petugas, namun masih masuk dalam kategori puas, menunjukkan bahwa belum optimalnya penampilan petugas pelayanan dalam benak pengunjung dari sisi keramahan, kesopanan, kedisiplinan, kerapihan, daya tanggap, dan kejujuran.

Pasar Pancingan Bilebante yang nampak jauh lebih sederhana dengan spot-spot selfie yang tidak banyak dan fasilitas penunjang yang tidak sebagus Botanic Garden justru mampu memberikan kinerja pelayanan yang lebih baik. Sementara itu, perbandingan kinerja unsur-unsur pelayanan tersebut dapat dilihat pada table $4.14 \mathrm{di}$ laporan penelitian.

Secara umum terdapat 17 unsur pelayanan pada Pasar Pancingan yang memberikan kinerja lebih baik daripada Botanic Garden dan ada 13 unsur pelayanan lainnya pada Botanic Garden yang lebih baik daripada Pasar Pancingan dalam persepsi pengunjung masing-masing dilihat dari sisi indeks kepuasan pengunjung. Hari beroperasi ternyata memberikan derajat kepuasan yang sama kepada pengunjung Botanic Garden dan Pasar Pancingan, meskipun hari beroperasinya jauh berbeda. Botanic Garden bukan setiap hari dari pagi hingga sore, sementara Pasar Pancingan hanya buka setengah hari pada hari minggu. Pengunjung Pasar Pancingan tidak banyak menuntut agar obyek tersebut dibuka setiap hari sebagaimana yang dilakukan oleh Botanic Garden, karena merasa bahwa kegiatan berwisata lebih cenderung dilakukan pada hari Minggu.

Dari uraian yang sederhana tersebut mudah diperoleh gambaran bahwa pengunjung Pasar Pancingan tidak terlalu memikirkan kondisi yang lebih baik daripada Botanic Garden, sehingga sentuhan sedikit dan sederhana terhadap unsur pelayanan 
dipandang sudah cukup memuaskan mereka. Nama Pasar Pancingan yang terkesan sederhana, mudah diingat, tradisional, dan mengindonesia dapat menampilkan kesan merakyatnya obyek wisata tersebut, sehingga kesederhanaan Pasar Pancingan akan memberikan kepuasan yang kurang lebih sama dengan Botanic Garden yang memiliki kesan penampilan lebih mentereng, lebih luas, lebih lengkap, dan lain-lain.

\section{Posisi Persaingan dalam Matriks Konsumen}

Analisis mengenai tingkat kepentingan nilai guna yang dipersepsikan pengunjung obyek wisata Pasar Pancingan Desa Bilebante dan Botanic Garden yang tersusun atas dua tingkatan, yakni dimensi global dan dimensi PUV (unsur-unsur pelayanan pada dimensi global). Oleh karena itu, terdapat dua bobot dalam perhitungan tingkat kepentingan nilai guna yang dipersepsikan ini yakni dimensi global dan dimensi detailnya, sebagaimana terlihat pada tabel 4.15. Terlihat bahwa secara umum seluruh dimensi global (Lingkungan, Fasilitas Pendukung, Waktu Operasi, Lokasi/tempat, Komunikasi, Penampilan Petugas dan Tarif/harga) dipandang memiliki tingkat kepentingan relatif sama. Hal ini bisa dilihat dari nilai skor masing-masing dimensi global yang hampir mirip besarnya, tidak terlalu jauh bedanya. Meskipun demikian, tetap dapat dilihat perbedaan tingkat kepentingan masing-masing dimensi global dimaksud.

Responden menganggap komunikasi merupakan bagian dari dimensi global yang terpenting dengan tingkat kepentingan sebesar 15,54\%, sedangkan harga dipandang sebagai dimensi global yang paling tidak penting $(15,38 \%)$. Berdasarkan kenyataan ini dapat diketahui bahwa obyek wisata buatan perlu mengembangkan produk pada nilai guna dimensi global dengan tingkat kepentingan yang besar, seperti : komunikasi, fasilitas pendukung, lingkungan, dan lokasi/tempat.

Jika dilihat pada dimensi detail unsur-unsur pelayanan dapat diketahui bahwa akses transportasi pada dimensi global lokasi memiliki tingkat kepentingan tertinggi $(54,26 \%)$. Hal ini dapat dipahami mengingat akses transportasi ini tidak memiliki banyak dimensi detail (dua unsur), sehingga nilai dimensi globalnya tinggi. Di luar faktor ini, Unsur hari operasi merupakan dimensi detail yang dipandang memiliki tingkat kepentingan tertinggi juga $(50,13 \%)$, sedangkan luas kawasan obyek wisata pada dimensi global lingkungan dianggap paling tidak penting (11,51\%). Dengan demikian, perusahaan harus memperhatikan pengembangannya ke arah dimensi detail dengan tingkat kepentingan tinggi ini.

Analisis tingkat kepentingan ini belum cukup bagi obyek wisata untuk mengetahui posisinya di pasar dibandingkan dengan produk pesaing. Untuk itu, tingkat kepentingan ini harus dikaitkan dengan kinerja perusahaan dalam persepsi pelanggan sehingga akan menghasilkan nilai guna sesungguhnya yang dipersepsikan oleh pengunjung, dengan mengkalikan tingkat kepentingan dengan kinerja produk seperti yang terlihat pada table 4.16 laporan penelitian.

Dari hasil perhitungan tersebut terlihat bahwa kinerja pelayanan setiap dimensi detail unsur-unsur pelayanan masing-masing obyek wisata (Pasar Pancingan dan Botanic Garden), karena analisis ini berkaitan dengan kinerja perusahaan dibandingkan dengan pesaingnya, sehingga untuk lebih memperjelas perbandingan kinerja tersebut perlu diproses lebih lanjut dengan membandingkan PUV setiap unsur pada masingmasing obyek wisata untuk melihat keunggulan masing-masing berdasarkan nilai guna 
dalam persepsi pengunjung. Melihat kinerja masing-masing unsur pelayanan melalui pendekatan kepuasan pengunjung semata dipandang masih belum cukup memberikan gambaran yang utuh. Mengkaitkan kepuasan pengunjung dengan tingkat kepentingan yang dipersepsikan dan bobot nilai masing-masing unsur dalam dimensi global dipandang dapat lebih menggambarkan kondisi yang sebenarnya.

Langkah berikutnya adalah dengan membandingkan kinerja baik dan kinerja buruk masing-masing unsur pelayanan pada kedua obyek wisata tersebut. Hasil perbandingan tersebut dalam bentuk yang sederhana dapat dilihat pada Tabel 4.17 dalam laporan penelitian. Terlihat dengan jelas perbedaan kinerja dari masing-masing unsur pelayanan di setiap obyek wisata dalam berdasarkan nilai guna yang dipersepsikan oleh pengunjung. Berdasarkan hasil itu terlihat ada perbedaan hasil dengan Tabel 4.14. dengan Tabel 4.17 yakni pada unsur luas kawasan obyek wisata yang memperoleh kinerja nilai guna yang sama sebagaimana pada unsur jam buka.

PUV dimensi detail tersebut selanjutnya dipilah lagi dalam PUV dimensi global sehingga dapat diketahui kinerja pelayanan dimensi global masing-masing obyek wisata. Seluruh PUV yang termasuk dalam setiap dimensi global dijumlahkan untuk memperoleh PUV dimensi global. Untuk lebih lengkapnya PUV dimensi global ini dapat dilihat pada tabel 4 .

Tabel 4. PUV Dimensi Global

\begin{tabular}{|l|l|c|c|c|c|}
\hline No. & \multicolumn{1}{|c|}{ Dimensi Global } & $\begin{array}{c}\text { Pasar } \\
\text { Pancingan }\end{array}$ & $\begin{array}{c}\text { Botanic } \\
\text { Garden }\end{array}$ & Terbaik & Terburuk \\
\hline A & Kondisi Lingkungan & 0,539 & 0,536 & PP & BG \\
\hline B & Fasilitas Pendukung & 0,513 & 0,516 & BG & PP \\
\hline C & Waktu Operasi & 0,476 & 0,480 & BG & PP \\
\hline D & Lokasi / Tempat & 0,486 & 0,511 & BG & PP \\
\hline E & Komunikasi & 0,631 & 0,584 & PP & BG \\
\hline F & Petugas & 0,515 & 0,488 & PP & BG \\
\hline G & Tarif & 0,453 & 0,425 & PP & BG \\
\hline & Total & $\mathbf{3 , 6 1 5}$ & $\mathbf{3 , 5 4 1}$ & & \\
\hline
\end{tabular}

Sumber: Tabel 4.15 (dalam Laporan Penelitian)

Dari Tabel 4 tersebut terlihat jelas bahwa Pasar pancingan menampilkan kinerja pelayanan pada dimensi global yang lebih baik daripada Botanic Garden. Kelemahan Pasar Pancingan selama ini dalam pandangan pengunjung menyangkut dimensi Fasilitas Pendukung, Waktu Operasi dan Lokasi yang dalam kenyataanya memang lebih lemah dibandingkan dengan Botanic Garden. Dengan demikian pada dimensi global Kondisi Lingkungan, Komunikasi, Petugas, dan Tarif obyek wisata Pasar Pancingan kinerja dimensi globalnya lebih baik daripada Botanic Garden.

Kinerja PUV Dimensi Global tersebut kemudian dikaitkan dengan persepsi terhadap harga pada masing-masing obyek wisata tersebut. Persepsi pengunjung terhadap harga di kedua obyek tersebut berbeda, yakni lebih banyak pengunjung Pasar Pancingan yang menyatakan lebih murah dibandingkan persepsi harga pada Botanic Garden. Indeks persepsi harga terhadap kedua obyek wisata tersebut dapat dilihat pada Tabel 5 yang dapat digunakan untuk memetakan nilai pelanggan dari obyek wisata Botanic Garden dan Pasar Pancingan. 
Tabel 5. Indeks Persepsi Terhadap Harga

\begin{tabular}{|c|l|c|c|c|c|}
\hline \multirow{2}{*}{ No. } & \multirow{2}{*}{ Persepsi Terhadap Harga } & \multicolumn{2}{c|}{ Pasar Pancingan } & \multicolumn{2}{c|}{ Botanic Garden } \\
\cline { 3 - 6 } & & Jumlah & Skor & Jumlah & Skor \\
\hline 1 & Sangat Mahal & 0 & 0 & 1 & 1 \\
\hline 2 & Mahal & 8 & 16 & 5 & 10 \\
\hline 3 & Sedang & 12 & 36 & 38 & 114 \\
\hline 4 & Murah & 6 & 24 & 18 & 72 \\
\hline 5 & Sangat Murah & 30 & 150 & 6 & 30 \\
\hline \multicolumn{2}{|c|}{ Jumlah } & 56 & 226 & 68 & 227 \\
\hline \multicolumn{2}{|c|}{ Nilai Persepsi Harga } & $\mathbf{4 , 0 4}$ & & $\mathbf{3 , 3 4}$ \\
\hline
\end{tabular}

Sumber : Tabel 4.9 dalam laporan penelitian

Akhir dari seluruh proses analisis tersebut dapat dirangkum dalam sebuah tabel yakni menghubungkan PUV Dimensi Global dengan persepsi terhadap harga yang ringkasannya dapat dilihat pada tabel 6 . Semakin kecil angka perbandingan ini menunjukkan semakin rasionalnya obyek wisata dalam memberikan pelayanan, yakni semakin seimbangnya antara harga yang dibayarkan pengunjung dengan pelayanan yang diterimanya. Sebaliknya semakin tinggi perbandingan ini menunjukkan bahwa obyek wisata mampu memberikan kinerja yang lebih tinggi dibandingkan dengan harga yang dibebankan kepada pengunjung.

Tabel 6. Skor Perceived Price dan PUV

\begin{tabular}{|c|l|c|c|c|}
\hline No & Obyek Wisata & Persepsi Harga (PH) & PUV & PUV/PH \\
\hline 1 & Pasar Pancingan & 4,04 & 3,615 & 0,891 \\
\hline 2 & Botanic Garden & 3,34 & 3,541 & 1,060 \\
\hline Total & 7,38 & 7,156 & \\
\hline$\quad$ Rata-rata & 3,690 & 3,578 & \\
\hline
\end{tabular}

Sumber: Tabel 4 dan Tabel 5

Informasi yang diperoleh pada tabel tersebut selanjutnya dipetakan dalam sebuah grafik yang menghubungkan antara Nilai Guna dalam persepsi Pengunjung dengan Indeks Persepsi Terhadap Harga untuk masing-masing obyek wisata, sebagaimana dapat dilihat pada Gambar 2. sebagai berikut. 


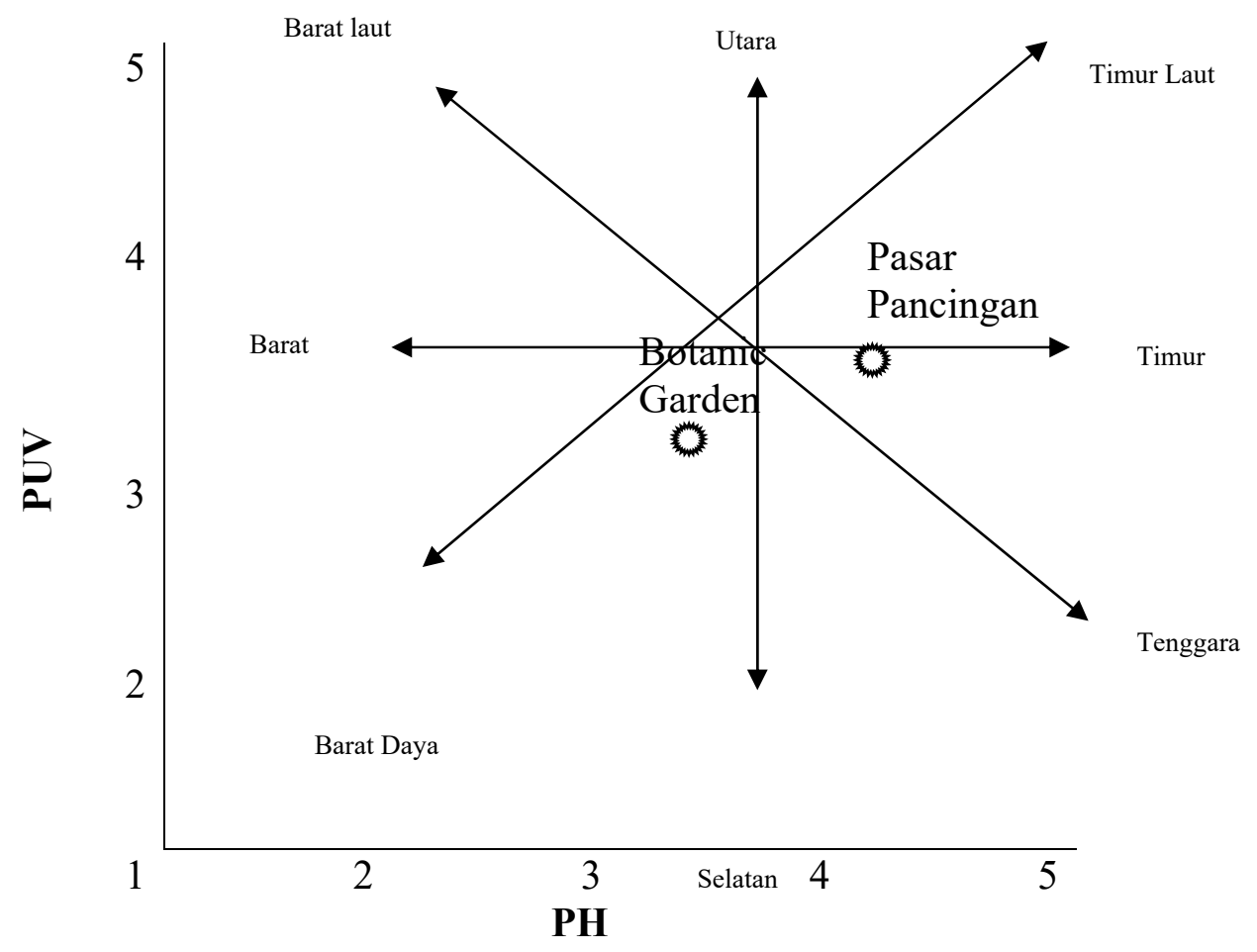

Gambar 2. Matriks Konsumen Obyek Wisata

Dalam gambar 2 terlihat bahwa Pasar Pancingan berada pada posisi yang lebih bagus dibandingkan dengan Botanic Garden secara rata-rata. Posisi Pasar Pancingan yang lebih dekat ke arah Timur menunjukkan bahwa Persepsi harga sudah baik karena berada di atas rata-rata persepsi harga dan di atas rata-rata nilai guna dalam persepsi pengunjung. Sebaliknya Botanic Garden berada pada posisi yang lebih lemah karena berada di bawah rata-rata nilai guna yang diperspesikan dan persepsi harga menurut pengunjung. Dengan demikian, jika Pasar Pancingan menginginkan memiliki kinerjsa yang lebih baik, maka sebaiknya menggunakan strategi yang mengarah pada bergesernya posisi tersebut ke arah Timur Laut yakni terjadinya keseimbangan antara nilai guna (PUV) dengan persepsi harga.

\section{KESIMPULAN DAN IMPLIKASI}

Hasil analisis menunjukkan Pasar Pancingan menerapkan persepsi harga rendah dan persepsi nilai guna yang tinggi, sedangkan Botanic Garden menerapkan persepsi harga lebih tinggi dengan persepsi nilai guna rendah. Selain itu, secara umum dilihat dari persepsi harga maupun persepsi nilai guna ditemukan bahwa Pasar Pancingan memiliki posisi yang lebih baik dibandingkan dengan Botanic Garden dalam persepsi pengunjung atau wisatawan. Meskipun demikian seluruh unsur-unsur pelayanan pada kedua obyek wisata ini masih belum memberikan kinerja yang baik, sehingga perlu mendapatkan perhatian serius untuk dikembangkan. 
Implikasi manajerial bagi pengelola Pasar Pancingan sebaiknya menerapkan strategi meningkatkan nilai guna yang mengarah pada pergeseran posisi Pasar Pancingan ke Timur Laut (posisi ideal) yang menunjukkan adanya keseimbangan antara persepsi nilai guna dengan persepsi harga. Selanjutnya Pasar Pancingan harus mempertahankan harga yang ada, karena persepsi harga saat ini sudah bagus dalam persepsi konsumen. Sedangkan Botanic Garden disarankan menerapkan strategi yang mengarah baik ke Utara maupun Timur, yakni meningkatkan PUV atau persepsi nilai guna sekaligus menaikkan persepsi harga. Kedua obyek wisata tersebut harus benarbenar memperhatikan nilai guna pada masing-masing unsur pelayanan yang selama ini belum banyak memberikan nilai kepuasan kepada pengunjung.

Sebagai tindak lanjut dari penelitian ini, diperlukan adanya kajian yang lebih spesifik dari faktor-faktor yang tercakup dalam analisis, sehingga mampu mengungkap kondisi bisnis pariwisata di Pulau Lombok secara umum.

\section{REFERENSI}

Hansen, Knud, Peter W. Heermann, Wolfgang Kartte, Hans-W. Micklitz, Wolfgang Pfletschinger, Franz Jurgen Sacker, Herbert Sauter, 2002, Undang-undang Larangan Praktek Monopoli dan Persaingan Usaha Tidak Sehat; PT. Katalis; Jakarta

Kotler, Philip, 2010, Manajemen Pemasaran, Jilid 1, Terjemahan, PT Indeks Kelompok Gramedia, Jakarta

Mahdi Kalbu, 2007, Analisis strategi Kompetetitf Operator CDMA Esia dengan Model matriks Konsumen, Jakarta

Mardiharto Tjokrowasito, 2008, Kebijakan Persaingan pada Industri Jasa Penerbangan Dilihat Dari Perspektif Perlindungan Konsumen Direktorat Hukum dan Hak Asasi Manusia, Bappenas, Jakarta

Rahman, dkk , 2011, Penciptaan superior customer value dalam persaingan merek kartu telpon seluler di kota Mataram

Thomas Nugroho, 2005, Analisis matriks konsumen untuk menciptakan Competitive advantage bagi J.W. Marriott Hotel Surabaya, Universitas Petra, Surabaya

Tony Sitinjak, Darmadi Durianto, Sugiarto, dan Holy Icun Yunarto, 2004, Model Matriks Konsumen Untuk Menciptakan Superior Customer Value, Gramedia, Jakarta 